\title{
ANTO GARDAŠ I HRVOJE KOVAČEVIĆ - DVIJE GENERACIJE AKCIJSKOGA DJEČJEG ROMANA
}

\section{Sažetak}

Ako u okviru hrvatskoga dječjeg romana pratimo razvoj akcijskoga tipa romana o poduzetnoj djeci željnoj pustolovina, možemo izdvojiti sljedeće autore kao bitne točke na razvojnoj liniji te vrste dječje knjiženosti, čiji su romani recepcijski izuzetno uspješni: Mato Lovrak, Ivan Kušan, Milivoj Matošec, Anto Gardaš i Hrvoje Kovačević.

Posljednju dvojicu, Gardaša i Kovačevića, osim što ih povezuje slavonsko podneblje kao životni prostor i kao prostorni lokalitet mnogih njihovih romana, povezuju još i mnoge druge strukturne, žanrovske, stilske i idejne činjenice. $U$ ovome radu usporedili smo njihova djela u kojima nalazimo određene poveznice. Obojica su se potvrdila kao majstori u vođenju radnje, stvaranju zapleta i neočekivanih obrata te spretnih raspletanja radnje. Kod obojice je u većini djela dominantna kompozicija detekcijskoga romana koja će u nekim djelima zadobiti čvrstu žanrovsku potku krimića, u nekima znanstvenofantastičnoga romana, a u nekima horora. Izvan ove klasifikacije ostaje i kod jednog i kod drugog književnika nekoliko romana u kojima autori u potpunosti izbjegavaju dotada uspostavljene šablone i u središte postavljaju ljudski karakter kao osnovicu strukture romana, pa bismo takav tip najbolje odredili kao roman lika. Sličnosti i razlike promotrili smo i s obzirom na generacijsku razliku između te dvojice autora.

Ključne riječi: Anto Gardaš; Hrvoje Kovačević; hrvatska dječja književnost; akcijski dječji roman; detekcijski roman.

\section{Uvod}

Anto Gardaš (1938. - 2004.) i Hrvoje Kovačević (1966.), dvojica slavonskih književnika koje dijeli vremensko razdoblje od trideset godina, izuzetno produktivni u svojem književnom stvaralaštvu, nanizali su seriju romana od kojih je gotovo svaki, kad bi bio objavljen, imao zajamčen uspjeh kod mladih čitatelja. U pokušaju otkrivanja 
ključa njihove popularnosti nameću se kao najuočljiviji elementi koji privlače dječju čitateljsku publiku akcija i pustolovnost kojima su im romani bremeniti.

Većina teoretičara dječje književnosti navodi upravo pustolovnost i akciju kao bitne konstitutivne elemente dječjega romana.

Ivo Zalar u svojoj knjizi Dječji roman u hrvatskoj dječjoj književnosti, koja je bila prva studija o dječjem romanu kod nas, razmatrajući što je zapravo dječji roman, dolazi do zaključka da ne možemo s istih pozicija pristupati romanu za odrasle i dječjem romanu, jer elementi koji se u jednome doživljavaju kao balast umjetničkoj vrijednosti u drugome označavaju zapravo ontološku vrijednost vrste, a riječ je upravo o pustolovnosti i akciji.

Druga prepoznatljivost o kojoj također treba nešto reći jest avanturistička crta dječjih romana. U ne baš brojnim prikazima ili kritikama dječje književnosti nađe se ponekad konstatacija, izražena, naravno, više kao zamjerka nego kao pozitivnost: „U romanu ima (navodim slobodno, prema sjećanju - primjedba autora) avanturističkih primjesa" Susreću se u recenzijama otprilike ovakve ili slično formulirane rečenice. U karakterizaciji Twainovih romana neki idu i dalje, pa ih nazivaju potpuno avanturističkim i spremni su ih svrstati u tu podvrstu. Njima je gotovo irelevantno što su akteri djeca, što je psihologija dječja, zgode dječje i zaigranost dječja. Njima je primarno uočljiv avanturistički element, jer ih na to i sam naslov upućuje, pa su nekako brzi u razvrstavanju i stavljanju, po mom sudu, pogrešnih etiketa. Jednako kao što su u zabludi i oni koji govore o „,avanturističkim primjesama“.

Avanturistika ili pustolovnost (da upotrijebim našu riječ) bitan je konstituens dječje psihe. Nije to nešto što odrasli njima nameću, već naprosto dio njih samih. Djeca sanjare o neobičnim zgodama, o uzbudljivim događajima, o velikim podvizima projicirajući često sebe u njih maštaju o dalekim putovanjima, o neočekivanim susretima, o svemu što ih može izvući i izbaviti iz sive, svakodnevne monotonije. Ako dakle pustolovine nisu njihova vanjska zbilja, one su dio njihove duševne stvarnosti. A zar ona i nije jednako važna ili čak važnija? Zar se nije i moderni roman odrekao slikanja konkretnih društvenih zbivanja u korist izražavanja nove senzibilnosti, vizija mašte i mozaika slika što ih tka svijest i podsvijest života?

Možda usporedba i nije najsretnija, ali ono osnovno što bih želio naglasiti jest to da nazočnost avanturistike u dječjim romanima nije nikakav začin ili dodatak nego je sastavni dio egzistencija dječje psihe, dječja vitalna potreba, te se potpuno opravdano nalazi u knjigama. Nikakva ih viša, umjetnička opravdanost ne može i ne smije izbaciti. (Zalar, 1978, 13) 
I Stjepan Hranjec, dvadeset godina poslije, u svojoj knjizi Hrvatski dječji roman pri određivanju dječjega romana kao književne vrste dolazi do sličnoga zaključka:

Dječji roman, nadalje, odlikuje se naglašenom pustolovnošću i akcijom. Komentirajući Kayserovu tipologiju, Flaker uz tip romana zbivanja spominje pojavu "trivijaliziranih varijanata“ u 19. stoljeću, što je osobitost avanturističkog i kriminalističkog romana. Ako je, prema tome, roman s naglaskom na fabuliranju namijenjen odraslome recipijentu manje vrijedan, $u$ dječjem je upravo to njegova kvaliteta. I opet s obzirom na maloga čitatelja, jer djecu obilježava neprestan nemir, dinamika, stalno kretanje, radoznalost duha, kada se pred njima otvara svijet, neprestano traženje i lutanje nepoznatim. Nije slučajno, štoviše, karakteristično je što je Defoeovo djelo doživjelo niz svjetskih izdanja i preradbi, niz imitacija, tzv. „robinzonijada“. Ako u romanu nema napete priče, ako, dakle, mladi čitatelj knjigom ne udovolji svome nemiru, takvi romani ubrzo bivaju zaboravljeni, a upravo poradi te akcije niz je romana uprizoreno, a neki su prenijeti na male i velike ekrane. (Hranjec, 1998.)

I suvremene teoretičarke dječje književnosti Dubravka Zima i Marijana Hameršak u svojoj najnovijoj knjizi Uvod $u$ dječju književnost naglašavaju pustolovnost i akciju kao nezaobilazne odrednice dječjega romana:

U taj široko zasnovan obzor asocijacija uklapa se i asocijacija o pustolovnosti često utjelovljena amblematskim likom pustolova Robinsona Crusoea, ili pak, u domaćim okvirima, njegovim jednako amblematskim dječjim pandanom šegrtom Hlapićem. U tome smislu zanimljivo je primijetiti isto tako da odrednice karakteristične za spomenute dječje romane - dječji likovi, dječačke družine, pustolovnost i dječja ili preciznije dječačka akcija - unekoliko funkcioniraju i kao odrednice kojima se u izvanstrukovnom kontekstu opisuje ili asocira dječja književnost u cjelini (Zima, Hameršak, 2015, 197).

Osim što su pustolovnost i akcija bitni elementi većine dječjih romana, u nekim romanima ti elementi toliko prevladavaju da su romani žanrovski određeni upravo kao akcijski romani i baš takvi romani uživali su uvijek veliku popularnost kod dječjih čitatelja.

U svojoj antologiji hrvatskoga dječjeg romana Prozori djetinjstva I i II Joža Skok (Skok, 1991.) razvrstava dječje romane prema strukturnoj tipologiji u kojoj izdvaja akcijski dječji roman i pustolovni dječji roman, iako i druge vrste koje je izdvojio 
imaju često mnogo akcijskih i pustolovnih elemenata, kao naprimjer dječji krimić, znanstvenofantastični dječji roman, povijesni dječji roman, humoristički dječji roman i dr.

Ako pokušamo u razvoju hrvatskoga dječjeg romana izdvojiti najplodnije autore izrazito popularnih, naglašeno akcijskih romana, tu će se svakako naći Mato Lovrak, Ivan Kušan, Anto Gardaš i Hrvoje Kovačević.

Popularnost Lovrakovih romana Ivo Zalar objasnio je ovako:

Zaista nema u njima nikakvih naročitih stilski markiranih mjesta, odstupanja od konvencionalnih normi govora koja bi izrazu dala specifičnu obojenost, ali se tim jednostavno ispričanim sadržajima krije sve ono što karakterizira najbolje dječje romane svijeta: zanimljiva fabula, napetost zbivanja, iskonska dječja psihologija, avanturističnost i akcionost, težnja za udruživanjem u kolektiv i sukobi u njemu, naivnost $\mathrm{i}$ iskrenost u pogledima i postupcima, vedrina i humor, ukratko sve ono od čega se i u običnom svakodnevnom životu sastoji uzbudljiva drama djetinjstva. (Zalar, 1978., 27)

Uglavnom se svi kritičari slažu da je akcija u Lovrakovim romanima sazdana od igre, koja čini osnovu prirode djeteta, i potrebe da oblikuju svijet po svome, a iz nje se razvija ideja zajedništva koja rezultira zajedničkim korisnim pothvatima ili sukobima. U svim romanima možemo pratiti proces neprestanoga aktiviranja i diferenciranja dječjih junaka koji vodi optimističnom završetku.

Lovrakove utilitarne dječje akcije Kušan je zamijenio djeci bližima igrivim akcijama unoseći elemente krimića, što će slijediti mnogi dječji pisci. Postavlja u romanu i osnovnu kompozicijsku shemu detektekcijskoga postupka.

Dvadesetak godina (od objavljivanja prvog romana 1933.) Lovrak je dominirao u popularnosti svojim akcijskim romanima, sljedećih dvadesetak i više godina (od svojeg prvog romana 1956.) prevlast preuzima Kušan, a onda se početkom osamdesetih godina pojavljuje Anto Gardaš i postaje jednim od najčitanijih pisaca akcijskih romana, da bi mu se krajem devedesetih pridružio Hrvoje Kovačević, koji je danas najplodniji autor takvoga tipa akcijskoga romana.

\section{USPOREDBA GARDAŠEVIH I KOVAČEVIĆEVIH ROMANA}

Dvojica slavonskih pisaca, Anto Gardaš i Hrvoje Kovačević, koje dijeli generacijski razmak od trideset godina, osam godina preklopili su se u pisanju, što ih je učinilo suvremenicima. Zajednička im je velika popularnost među djecom te ista vrsta romana (akcijskog) temeljena na detekciji. Obojica postavljaju na početku neku 
enigmu koju će dječji junaci tijekom romana pokušavati riješiti i do kraja romana će u tome uspjeti. Ali ne može se reći da pišu šablonske romane jer u tu osnovnu shemu ugrađuju različite varijacije i tematske i strukturne prirode.

Na prvoj razini možemo ih podijeliti na mimetične i fantastične.

Među fantastičnima razlikuju se znanstvenofantastični i horori (romani strave i užasa), a mimetični su većinom krimići, koje možemo dalje podijeliti na prave krimiće i prividne krimiće.

\subsection{Fantastični roman}

Fantastični romani obaju autora odlikuju se istaknutom pustolovnošću, vještinom dobroga fabuliranja sa spretnim zapletanjem i raspletanjem radnje, napetošću postignutom postavljanjem junaka u bezizlazne situacije koje se neočekivano rješavaju, brzim pripovjedačkim ritmom, koji također pogoduje stvaranju napetosti te humorom. Sve su to odlike koje inače nalazimo kod ovih autora i u romanima koje smo žanrovski drukčije odredili. Znanstvena fantastika kod njih je zapravo stilizirana i znanost je reducirana u korist fantastike. Često se iscrpljuje u rekvizitima koji čitatelja asocijativno upućuju na žanr znanstvene fantastike kao što su svemir i izvanzemaljci. No obojica autora pišu i fantastične romane u kojima fantastika ne gravitira znanosti nego iracionalnome. Ubacujući okultne i mistične elemente koji rezultiraju osjećajem jeze i tjeskobe, stvorili su zapravo dječji horor roman.

\subsubsection{Znanstvenofantastični roman}

Iako je prva Gardaševa knjiga za djecu bila zbirka priča, dječje je simpatije zapravo pridobio svojim znanstvenofantastičnim romanima Ljubičasti planet, Bakreni Petar i Izum profesora Leopolda, u kojima je stvorio lik dječaka Mirona, koji se poslije pojavljuje i u njegovim mimetičnim romanima. Riječ je o zanimljivoj trilogiji u kojoj se autor služi uobičajenim motivima toga žanra (putovanja u svemir, dolazak izvanzemaljaca, vremenski stroj). U prvom dijelu, Ljubičasti planet, Gardaš čitatelja odvodi u svemir na udaljeni planet gdje je sve više-manje projekcija elemenata koji postoje na zemlji, samo u nekim novim maštovitim kombinacijama. Iako je riječ o naprednijoj civilizaciji, za spas planeta bio im je potreban znanstvenik sa Zemlje i osobito njegov nestašni sinčić Miron. U konačnici to je priča o solidarnosti među bićima bez obzira na podrijetlo. U drugom dijelu Bakreni Petar izvanzemaljac dolazi na Zemlju i zajedno s Mironom i njegovim prijateljima istražuje podzemne hodnike osječke tvrđave. Neistraženi podzemni hodnici vrlo su zahvalan ambijent za stvaranje tajnovitoga i zastrašujućega ugođaja. U osnovi romana jest sukob dviju suparničkih dječačkih družina. Jedna družina bavi se arheologijom i numizmatikom iz 
ljubavi prema starinama, a druga skuplja vrijedne starine isključivo iz koristoljublja. Autor vodi radnju bremenitu dječačkim nadmudrivanjima, uhođenjima, izdajama, zamkama, a vrhunac čini bitka za podzemno sklonište. Sve je to potpuno u duhu romana o dječjim družinama, ali jedan je od dječaka izvanzemaljac, što se ne zna od početka nego autor izvanzemaljsko podrijetlo Bakrenog Petra otkriva i čitatelju i ostalim protagonistima romana postupno navodeći neobičnosti u dječakovu ponašanju. Elementi znanstvene fantastike tu su zapravo u službi ideje o dječjoj potrebi za kolektivom, zajedničkom igrom i akcijom. U trećem dijelu Izum profesora Leopolda Gardaševi junaci nehotično pokrenu vremenski stroj, koji ih prebaci u 351. godinu, u vrijeme bitke za rimsku Mursu, vjerojatno najkrvavije bitke vođene u 4 . stoljeću. Tako djeca sudjeluju u događajima koji su utjecali na razvoj kasnijih povijesnih zbivanja u Europi. Došljaci iz 20. stoljeća ne mogu promijeniti tijek povijesti u 4. stoljeću, ali poznavanje povijesnih činjenica itekako im pomaže da ne zaglave u povijesnom vrtlogu. Djeca 20. stoljeća superiorna su ljudima iz 4. stoljeća dok raspoloživa tehnika ne zakaže. Zahvaljujući povijesnim činjenicama kao i detaljnom prikazu kostima i ambijenta, dobili smo zanimljiv spoj jedne futurološke i povijesne projekcije.

Element kojim se Gardaš obilato koristi u strukturi svojih romana jest paralelizam radnje. U Ljubičastom planetu pratimo istovremena događanja u raznim svemirskim prostorima (Zemlja - Sanon - planetoid), a u Izumu profesora Leopolda pratimo „istovremena" događanja u različitim stoljećima (što rade djeca zalutala u 4. stoljeće - što rade njihovi roditelji u 20. stoljeću). Istom tehnikom koristi se i u Bakrenom Petru, no kako je tu često težište pomaknuto iz sfere konkretne akcije na psihološka proživljavanja likova, Gardaš predočava istovremena razmišljanja i psihička proživljavanja likova na različitim mjestima, ali povezana istim problemima. Takvom tehnikom pripovijedanja autor maksimalno potiče čitateljevo zanimanje za ono što će slijediti. Napetost uvijek doseže kulminaciju pred kraj, upravo u paralelnom prosedeu - tko će prije - o čemu ovisi hoće li se junaci uspjeti vratiti u svoj prostor, odnosno vrijeme.

Žanru znanstvene fantastike Gardaš se vratio i u jednom od svojih posljednjih romana namijenjenih mladoj čitateljskoj publici, Tajna jednog videozapisa. Radnja je utemeljena na zbiljskom događaju koji je početkom 20. stoljeća uzdrmao svijet, neobjašnjivom eksplozijom 1908. godine u Sibiru. Autor mu pripisuje uzroke u prijateljskom posjetu izvanzemaljaca. Klonirani zameci igrom slučaja dospiju na različite strane svijeta, a kad se iz njih razviju djevojka i mladić, slijedi izrazito dinamična radnja koja je diktirana tajanstvenim kretanjima izvanzemaljaca s očitim postojanjem cilja koji će čitateljima biti otkriven tek na kraju romana, zahvaljujući videozapisu. Prema Stjepanu Hranjecu, „Gardaš je svakako prvo SF književno ime u dječjoj novijoj hrvatskoj književnosti“. (Hranjec, 2006.) 
Hrvoje Kovačević svoj znanstvenofantastični roman Tajna crne kutije također piše po strukturi kriminalističkog romana, ali unosi izvanzemaljce, odnosno izvanzemaljsku inteligenciju koja virtualnim putem, pomoću suvremene tehnologije, prodire na Zemlju zbunjujući njezine stanovnike. I ovdje je riječ o naprednijoj civilizaciji kojoj će uspješno doskočiti dječak Vito. Njegova domišljatost potaknuta kompjutorskim igrama razvila se $u$ logično zaključivanje koje ga je dovelo do uspješnog razrješenja problema koji su mogli ostaviti velike posljedice na Zemlji. Iako Hrvoje Kovačević nije htio lik stvoren u prvom romanu voditi dalje u svoje nove romane poput Gardaša nego u svakom romanu profilira novoga dječjeg junaka, ipak primjećujemo da su glavni junaci, iako se različito zovu, karakterno vrlo slični. Našavši se u nekoj neugodnoj, nerijetko opasnoj situaciji, Kovačevićev dječji junak obično je u početku zbunjen i zastrašen, ali ubrzo se odlučuje za akciju, počinje logično povezivati činjenice, a kad uzmanjka logičnih poveznica, poslužit će i mašta da popuni prazninu. Tako je i u ovom romanu Vito, ugrožen s nekoliko strana (jači i agresivni dječaci u školi, mjesni delinkventi, izvanzemaljci) uspio domišljatim potezima izbjeći sve postavljene zamke i nametnuti se kao lik koji ne rješava probleme snagom ili bježanjem nego svojom pameću istesanom u kompjutorskim igrama. Vito ujedno rješava i obiteljske probleme, zasijane u prošlosti. Zahvaljujući njemu, sve sjeda na svoje mjesto - i u obitelji, i u školi, i u gradu.

Gardaševim i Kovačevićevim dječjim znanstvenofantastičnim romanima zajednička je ideja o dječjoj superiornosti nad naprednijim svemirskim inteligencijama. Međutim, u izboru rekvizita kojima ostvaruju znanstvenofantastični ugođaj vidljiva je generacijska razlika između te dvojice književnika. Dok se Gardaš fokusira na opredmećenje svemirskih lokacija i izvanzemaljce kao fizička bića, Kovačevića više zanima virtualni svijet stvoren izvanzemaljskom inteligencijom i mogućnosti njegova utjecaja na Zemlju.

\subsubsection{Horor}

Kombinaciju spoja povijesnih činjenica i elemenata fantastike Gardaš nastavlja i u romanu Prikaza, ali tu u fantastičnoj komponenti znanost zamjenjuje okultnim i mističnim, pa možemo govoriti o dječjem hororu. Miron se sa svojim prijateljima nesvjesno nađe na putu skupini mladih provalnika koji žele opljačkati vrijednosti iz valpovačkog dvorca. U dobro poznatoj Gardaševoj maniri paralelizma, ovdje pratimo tri radnje (dječja iskapanja - pripreme provalnika - legendu o bijeloj ženi). Pučka vjerovanja i neobjašnjivi događaji (koje priređuju provalnici) potenciraju strah, tjeskobu i nelagodu. Vrtlar u dvorcu priča dječacima legendu o bijeloj ženi (Mariji Stilinović, koja je tragično skončala za turske opsade dvorca 1543., pa njezin duh luta dvorcem), čija magična moć sve više prema kraju romana raste i nadvladava um 
nesretnoga vrtlara, koji zapada u oniričko stanje. Tajanstvenost događaja ne dobiva nikakvo racionalno, znanstveno objašnjenje, pa ostaje kao jedino moguće objašnjenje religijsko - prelazak u drugu egzistenciju. Uz uobičajene Gardaševe elemente pustolovnoga i kriminalističkoga romana, ovdje imamo transformaciju fantastičnih elemenata iz znanstvenih u okultne i mistične, čime se roman postavlja dominantno kao horor.

Hrvoje Kovačević svoj je roman Tajna graditelja straha napučio stalnim mjestima tipičnim za tu književnu vrstu: mrtvaci oživljuju, pojavljuju se čudovišta, postoji „ukleta“ kuća, eksterijeri izazivaju jezu poput groblja noću, mračne šume itd. Nižu se neobjašnjivi događaji koji siju strah i među djecom i među odraslima. Čitatelj dugo očekuje neko racionalno objašnjenje za neuobičajene događaje. Autor nekoliko puta i nudi racionalno objašnjenje, ali onda ponovno zavrti priču u irealnom smjeru. Strah koji je zahvatio najprije Mesničku ulicu, a zatim i cijelo mjesto, pojavom neobjašnjivih događaja nastao je iz iskonskog uvjerenja da je nepoznato i neobjašnjivo uvijek produkt zlih sila. Uzrok neobičnih događaja jest neobično sluzavo gadno stvorenje crvenih očiju poslije susreta s kojim se svi izbezumljuju i počinju čudno ponašati.

Tajna Stubičkih Toplica nije tipičan roman nastao u maniri horora, ali je prožet atmosferom neočekivanoga, neobjašnjivoga i nadljudskoga gdje se napetost priče pojačava stalnim prizvukom straha od smrti, prolaznošću i krhkoću života. U romanu pratimo dvije naizgled nepovezane radnje. Jedna se odvija u Zagrebu i prati dječaka Hrvoja Filipeca i njegova oca u ordinaciji neobične psihijatrice; druga se odvija u Stubičkim Toplicama, gdje upoznajemo galeriju likova, svih okupljenih oko zajedničkog misterija - nestanka djevojčice Dubravke Vrabec. Dječaka Hrvoja i izgubljenu djevojčicu isprva povezuje samo činjenica da su oboje iz malenoga grada na sjeverozapadu Hrvatske. No, kako će se ispostaviti, veze između naizgled nepovezanih likova s vremenom postaju mnogo jasnije. Ideja o podsvjesnoj i neraskidivoj povezanosti ljudi čini dominantan motiv natprirodnoga koji prožima roman. Djevojčica Dubravka izašla je usred noći, u spavaćici i papučama, te joj se od tada gubi svaki trag. Nakon toga događaja sedamnaestogodišnji Hrvoje svake noći mjesečari - nesvjesno izlazi iz kuće i staje pokraj ceste, pokraj prometnoga znaka na kojemu piše naziv njegova grada. Na kraju romana ispostavlja se da je Dubravka na tom prometnom znaku napisala poruku posebnom bojom koja postaje vidljiva samo u dodiru s vlagom. Djevojčica se nadala da će u doticaju s kišom ta poruka (od samo dvije riječi) postati vidljiva i Hrvoju. Taj ju je čin nakraju i koštao života jer pogiba pod kotačima neodgovornoga vozača. Iako misterij njezina nestanka biva realno objašnjen te iako je značenje prometnoga znaka u romanu razotkriveno, misterij Hrvojevih mjesečarenja ipak ostaje u području nadzemaljskoga - nečega što je podsvjesno, natprirodno i nedokučivo. 
Dok su Gardašu izvori za stvaranje ugođaja strave i užasa uglavnom folklornog podrijetla (legende, vjerovanja), Hrvoje Kovačević traži izvore za takav ugođaj u ljudskoj svijesti i podsvijesti, što opet možemo očitati kao generacijsku razliku u pristupu istom žanru.

\subsection{Mimetični romani}

Mimetični romani obaju autora najčešće su krimići koji se odlikuju vrsnim umijećem fabuliranja, vještom kompozicijom, brzim pripovjednim ritmom, naglašenom dozom pustolovnosti i ostvarenom velikom napetošću. No u određenom broju romana autori završetkom iznevjeravaju čitateljeva očekivanja jer se ispostavlja da zapravo nije bilo nikakvoga kriminalističkog čina.

\subsubsection{Pravi krimić}

Likove stvorene u svom prvom znanstvenofantastičnom romanu (brat Miron, sestra Melita, njihovi prijatelji i roditelji) Gardaš provodi i kroz svoje krimiće. U vrlo jasnu formulu kriminalističkoga romana građenoga na detekcijskoj metodi, Gardaš unosi i sasvim aktualne društvene probleme suvremenoga svijeta, kao što su ekološka problematika, problem droge, maloljetničke delinkvencije...

Duh u močvari krimić je naglašene ekološke dominante. Naime Gardaš svoje dječje junake dovodi u zaštićeno područje Kopačkoga rita, gdje se djeca potvrđuju kao uspješni detektivi u otkrivanju lovokradice. Uz napetu kriminalističku fabulu autor upoznaje čitatelje sa životinjama i životom u prirodi, odnosima ljudi i prirode, s uništavanjem prirode, ali i čuvanjem, i nadasve njezinom vrijednosti za pojedinca i za čovječanstvo.

U romanu Koliba u planini Gardaš iste junake odvodi na padine Krndije, gdje djeca uspješno razotkrivaju pokušaj pohranjivanja otrovnoga otpada u šumama Krndije. I jedan i drugi roman možemo odrediti kao ekološke krimiće u kojima djeca brane prirodu od nesavjesnih odraslih.

U romanu Miron u škripcu Gardaševi dječji junaci, već dobro poznati čitateljima, istražuju kamo je nestala sestra jednoga dječaka, pri čemu se sukobljavaju s opasnom bandom starijih dječaka i zaranjaju u otužni svijet droge i maloljetničke delinkvencije. Autor radnju smješta u urbane sredine Osijeka i Zagreba koristeći se postupcima krimiromana, pa vodi čitatelja kroz više istovremenih radnji, prateći glavne protagoniste i ne dopuštajući da i u jednom trenutku popusti napetost zahvaljujući ubačenim prijetnjama, otmicama, potjerama, šifriranim porukama i ucjenama.

U romanu Krađa u galeriji ili sve se urotilo protiv malog Terzića Gardaš ubacuje Mirona usred kriminalističke afere krađe slika iz osječke galerije u kojoj je odrađivao 
učeničku praksu njegov prijatelj. Zahvaljujući Mironovoj oštroumnosti, istina će izaći na vidjelo, a Gardaš u napeti krimić uspijeva nenametljivo ubaciti čitatelju zanimljive informacije o likovnim umjetnicima.

Za razliku od Gardaša, Kovačević voli u svakom romanu izgraditi novi lik dječjega junaka (samo u jednome se pojavljuje junak iz prijašnjeg romana). Iako se i Kovačević u nekim svojim romanima dotiče aktualnih društvenih događanja, npr. gospodarski kriminal u koji su upetljani političari, ipak se radije bavi odnosima unutar obitelji i među prijateljima.

U svojem prvom romanu, Tajni Ribljeg Oka, Kovačević je izgradio kostur koji će rabiti u većini kasnijih dječjih romana. Riječ je o žanru dječjega kriminalističkog romana u kojemu je dijete dobrovoljni istražitelj, njegovo istraživanje ne počinje od nekog iznenadnog događaja nego od opažanja koje pobuđuje sumnju. Vrijeme radnje uglavnom je kratko jer se fabula zaplete i rasplete u nekoliko dana, u ovom slučaju $\mathrm{u}$ točno tjedan dana. U svakom romanu postavljena je tajna koju dječak protagonist razrješava uz pomoć prijatelja ili prijateljice, a ako zadatak prijeđe dječje mogućnosti, pronalazi neku odraslu osobu od koje će zatražiti pomoć kako bi se sve privelo sretnom završetku. Usput se gradi i emocionalni odnos prema djevojčici koja je u službi pomagača. Napetost postiže stvarajući na prvi pogled bezizlazne situacije u kojima se junak zatekne, da bi se zatim napetost razvodnila u banalnosti sljedeće situacije, pa time autor zapravo svako uzbuđenje razblažava humorom koji proizlazi iz spomenute tehnike pripovijedanja. Glavni je junak jedanaestogodišnji dječak Domagoj, na neki način sljedbenik Kušanova Koka i Gardaševa Mirona, dječaka koji su također rješavali kriminalističke zaplete i uz čije su pustolovine odrastale generacije mladih čitatelja.

U Tajni šutliivog dječaka iznenada, na vrlo bizaran način, nestaje dječak iz razreda, a akciju potrage više slučajno nego svojevoljno preuzima njegov najbolji prijatelj Krizma. Iako nije volio uzbuđenja, zahvaljujući sklopu čudnih okolnosti, postaje glavnim akterom potrage u napetoj atmosferi fizičkih napada, jurnjava, skrivanja te krivih pretpostavki nametnutih čitatelju. Uzbuđenja se tu ublažavaju humorom koji proizlazi iz karikiranja likova. Od šutljivog dječaka na kojega nitko nije obraćao pozornost, autor dovodi čitatelja do razotkrivanja kriminalnog djelovanja dotad uspješnih poslovnih ljudi i političara.

\subsubsection{Prividni krimić}

Obojica autora imaju i romane koji strukturom u potpunosti odgovaraju krimiću, ali, kako smo već spomenuli, nakraju se razotkriva da zapravo nije počinjen nikakav kriminalni čin.

Naprimjer Gardaš u Pigulici gradi krimiroman komplicirane fabule s mnogo zagonetaka da bi rasplet opovrgnuo postojanje bilo kakvoga kriminalnog djela i sve 
sveo u okvir dječje igre i zabave. Naime, Gardaš je stvorio komičan lik male, divlje seoske djevojčice Pigulice, koja se kreće na realnom tlu, ali svojim maštovitim kombinacijama nastoji nadići realnost i učiniti je ljepšom i zanimljivijom, pa je Hranjec naziva slavonskom Pipi Dugom Čarapom (Hranjec, 2006.). Ona je boravak svojih prijatelja iz grada, Mirona i Melite, izrežirala u stilu uzbudljive i opasne avanture jer se voli igrati, voli zapovijedati, voli biti glavna.

Kovačević je pak u Tajni Zlatnog Zuba izgradio vrlo uzbudljiv kriminalni vrtlog u koji upadaju djeca, ali nakraju saznajemo da su sve velike opasnosti u kojima su se zatekla djeca bile zapravo fikcijske, nastale u imaginaciji Davorova oca, koji je iskoristio svoj dramski talent da zorno ukaže sinu i njegovim prijateljima na strahote do kojih bi njihovo nepromišljeno ponašanje moglo dovesti i da ih na taj način pouči opasnostima koje vrebaju u životu ako zatomimo savjest i pokušamo učiniti nešto neprilično. Riječ je o specifičnom didakticizmu.

Slično se i u Tajni Zantara vidovnjaka nakraju sve razotkriva kao plod mašte nezadovoljnoga malog čovjeka koji nikada nije bio zapažen te je sam sebi htio dati na važnosti i osvetiti se ljudima koji na njega nisu uopće obraćali pozornost, a stvarnoga kriminalnog čina niti nema osim spominjanja ubojstva u uvodnom dijelu za koje je počinitelj kažnjen. Ali upravo to spominjanje zločina na samom početku navodi čitatelja na očekivanje krimića.

U Tajni šaptača lubenicama Kovačević gradi neobičan zaplet - iz specijalne bolnice za medicinsku rehabilitaciju misteriozno nestaju stare, teško pokretne pacijentice. Misteriozni nestanci u konačnici se pokazuju kao dobrovoljni odlazak starica koje su svoje obitelji željele nečemu poučiti. Kao u detektivskim zagonetkama, gdje je svaka informacija moguć trag koji će nas dovesti do razrješenja, tako je i intrigantan naslov romana znak za kojim se povodimo ne bismo li riješili novi misterij. No, dok kao čitatelji žedno tragamo za scenom u kojoj se pojavljuje ovaj misteriozni šaptač ili barem sočno ljetno voće (ili, točnije - povrće), pred nama se postupno otkrivaju jednako zanimljiv ambijent i likovi. Riječ je o prividnom krimiću jer je rješenje zagonetke prilično benigni događaj u kojem ne postoji „negativac“, pa čak ni velik misterij. No, intrigantan naslov, kao i „mrvice“ informacija koje će se povremeno pronaći utkane u tkivo priče, u čitatelju stvaraju „„̌̌eđ za zagonetkom“, koja će ga nagnati da pažljivije čita između redaka. Taj će zanimljiv postupak omogućiti mlađim čitateljima da budu osjetljiviji za neke mnogo važnije i životne poruke koje se skrivaju u zabavnoj priči.

Razlika između Gardaševa i Kovačevićevih prividnih krimića leži u tome što kod Gardaša sve ostaje na razini dječje igre i želje za maštovitom i neočekivanom zabavom, a kod Kovačevića uvijek postoji neki ozbiljniji uzrok ili cilj iskonstruiranog krimimiljea na temelju kojega i junaci romana i čitatelji trebaju osvijestiti greške u svojem ponašanju ili ponašanju ljudi s kojima se svakodnevno susreću. Svaki Kovačevićev prividni krimić zapravo je vrlo poučan. 


\subsection{Iskorak iz akcijskih romana}

Obojica autora napravila su i iskorak iz akcijskih romana pokazavši da znaju i mogu pisati i drukčije.

Naprimjer Gardaš u romanu Filip, dječak bez imena gradi zanimljivu i potresnu priču o dječaku u potrazi za vlastitim identitetom. Dodijelivši Filipu sve osobine koje rese i glavne mu junake akcijskih romana (upornost, domišljatost, hrabrost, prijateljstvo, spremnost za pomoć), razvija ga dalje u izraziti refleksivni lik. Tako lik više nije definiran željom za pustolovinama nego problematiziranjem identiteta. Time se izdvaja iz galerije ostalih Gardaševih dječačkih likova. Od akcije postaje zanimljivije proučavanje ljudskoga karaktera i odnosa među ljudima.

Slično je učinio i Hrvoje Kovačević u svojem romanu Kuma Slava, brat i krava. Napustivši akciju i detekciju, u središte je romana postavio ljudski karakter. Zanemario je napetu fabulu, likovi prestaju ovisiti o akciji, a prostor i vrijeme $\mathrm{u}$ kojima djeluju suženi su. Glavni je predmet autorova interesa čovjekovo raspoloženje i odnos prema drugima. Svi protagonisti do kraja romana doživljavaju karakternu preobrazbu.

\section{ZAKLJUČAK}

Iz velike romaneskne produkcije i Gardaševe i Kovačevićeve izabrali smo romane koji su nam se učinili najreprezentativnijima kako bismo pokazali da obojica autora u svoja djela, bez obzira na žanrovsko određenje, uvijek ugrađuju i humane ideje koje se rađaju iz burnih događaja afirmirajući najpozitivnije, temeljne ljudske vrijednosti poput potrebe da budemo bolji jedni prema drugima, poruke o prihvaćanju onih koji su drukčiji od nas, poštovanja intelektualnih vrijednosti, tolerancije prema drugima, spremnosti na pomoć drugima... itd.

Vještinom pisanja ovi autori pokazuju kako su sjajno ovladali literarnim zanatom, zahvaljujući čemu imaju dobru recepciju kod djece, ali ipak nisu htjeli ostati samo na razini uzbudljive zabave, pa u gotovo sve romane unose vrijedne informacije i korisne svjetonazorske i životne putokaze čitateljima.

\section{Literatura}

Crnković, Milan (1990), Dječja knjižeunost. Zagreb: Školska knjiga.

Crnković, M. - Težak, D. (2002), Povijest hrvatske dječje književnosti od početaka do 1955. godine. Zagreb: Znanje.

Gardaš, Anto (1981), Ljubičasti planet. Zagreb: Mladost.

Gardaš, Anto (1984), Bakreni Petar. Zagreb: Mladost. 
Gardaš, Anto (1986), Izum profesora Leopolda. Zagreb: Mladost.

Gardaš, Anto (1988), Piglica. Zagreb: Mladost.

Gardaš, Anto (1989), Duh u močvari. Zagreb: Mladost.

Gardaš, Anto (1994), Filip, dječak bez imena. Zagreb: Znanje.

Gardaš, Anto (1995), Prikaza. Zagreb: Targa.

Gardaš, Anto (1999), Miron u škripcu. Zagreb: Alfa.

Gardaš, Anto (1999), Koliba u planini. Zagreb: Znanje.

Gardaš, Anto (2001), Krađa u galeriji ili Sve se urotilo protiv malog Terzića. Zagreb: Alfa.

Gardaš, Anto (2002), Tajna jednog videpzapisa. Zagreb: Alfa.

Hameršak, M. - Zima, D. (2015), Uvod u dječju književnost. Zagreb: Leykam international, d.o.o.

Hranjec, Stjepan (1998), Pregled hrvatske dječje književnosti. Zagreb: Znanje.

Hranjec, Stjepan (2006), Pregled hrvatske dječje književnosti. Zagreb: Školska knjiga.

Idrizović, Muris (1984), Hrvatska književnost za djecu. Zagreb: Matica hrvatska.

Kovačević, Hrvoje (1996), Tajna Ribljeg Oka. Zagreb: Znanje.

Kovačević, Hrvoje (1998), Tajna crne kutije. Zagreb: Znanje.

Kovačević, Hrvoje (2000), Tajna Zlatnog Zuba. Zagreb: Znanje.

Kovačević, Hrvoje (2003), Tajna graditelja straha. Zagreb: Znanje.

Kovačević, Hrvoje (2004), Kuma slava, brat i krava. Zagreb: Sysprint.

Kovačević, Hrvoje (2005), Tajna šutljivog dječaka. Zagreb: Znanje.

Kovačević, Hrvoje (2008), Tajna šaptača lubenicama. Zagreb: Znanje.

Kovačević, Hrvoje (2009), Tajna Stubičkih Toplica. Zagreb: Znanje.

Kovačević, Hrvoje (2013), Tajna Zantara Vidovnjaka. Zagreb: Školska knjiga.

Skok, Joža (1991), Prozori djetinjstva I. Zagreb: Naša djeca.

Skok, Joža (1991), Prozori djetinjstva II. Zagreb: Naša djeca.

Težak, Dubravka (2008), Portreti i eseji o dječjim piscima. Zagreb: Tipex.

Zalar, Ivo (1978), Dječji roman u hrvatskoj književnosti. Zagreb: Školska knjiga.

Zima, Dubravka (2011), Kraći ljudi. Povijest dječjeg lika u hrvatskom dječjem romanu. Zagreb: Školska knjiga. 


\section{Anto Gardaš and Hrvoje Kovačević - Two Generations of the Children's Action Novel Genre}

\section{Summary}

If we follow the development of the genre of action novels about resourceful children hungry for adventures, we can single out the following authors as significant points on a developmental timeline of this type of children's literature, whose novels have always been, reception-wise, extremely successful: Ivana Brlić-Mažuranić (with Hlapić the Apprentice), Mato Lovrak, Ivan Kušan, Milivoj Matošec, Anto Gardaš, and Hrvoje Kovačević.

The final two, Gardaš and Kovačević, are connected not only by their home region of Slavonia (also the spatial locality of their many novels), but also by many other facts related to structure, genre, style, and ideas. This paper shall compare their works in which we find certain connections. They have both been recognised as masters in leading the story, creating the plot and its unexpected twists, and coming up with crafty denouements. In most of their novels, both authors exhibit a dominant composition style of a detective novel, which is clearly presented through various genres - whether as a crime story, a science fiction novel, or a horror story. With both authors, several novels are kept outside any classification attempts. In these, the authors completely avoid established patterns and put the human character in the middle as a basis of the novel's structure, so we would classify this type of work as a character novel. We shall also examine the similarities and differences between the two authors from the aspect of the generation gap between them.

Keywords: Anto Gardaš; Hrvoje Kovačević; Croatian children's literature; children's action novel; children's detective novel.

Prof. dr. sc. Dubravka Težak

Učiteljski fakultet Sveučilišta u Zagrebu

Savska cesta 77, 10000 Zagreb

dubravka.tezak@ufzg.hr

Dr. sc. Marina Gabelica

Učiteljski fakultet Sveučilišta u Zagrebu

Savska cesta 77, 10000 Zagreb

marina.gabelica@ufzg.hr 